\title{
СЕСТРИНСЬКА СПРАВА ЯК ОБ’ЄКТ СОЦІОЛОГІЧНОГО АНАЛІЗУ
}

\author{
H. Фурсо
}

\author{
Тернопільський національний медичний університет \\ імені І. Я. Горбачевського МОЗ Украӥни
}

\begin{abstract}
Сформульовано і обгрунтовано основні тематичні напрямки соціологічних досліджень, спрямованих на вдосконалення та гуманізацію сестринської справи. Визначено місце і статус середнього медичного персоналу в сучасній структурі суспільства, і на цій основі обгрунтовано роль середнього медичного персоналу в досягненні позитивних результатів соціальної політики. На основі великого архівного матеріалу проведено аналіз історичного досвіду сестринської справи в країні, визначено особливості його розвитку. Виявлено основні етапи та особливості сучасного розвитку сестринської справи.
\end{abstract}

\section{NURSING AS AN OBJECT OF SOCIOLOGICAL ANALYSIS}

\section{N. Furso}

\section{Horbachevsky Ternopil National Medical University}

\begin{abstract}
The main thematic areas of sociological research aimed at improving and humanizing nursing are formulated and substantiated. The place and status of the nursing staff in the modern structure of society is determined, and on this basis the role of the nursing staff in achieving the positive social policy results is substantiated. On the basis of a large archival material, an analysis of the historical experience of nursing in the country was conducted, and the peculiarities of its development were determined. The basic stages and features of modern development of nursing were revealed.
\end{abstract}

Вступ. XXI століття супроводжується загостренням ряду проблем. Практично у всіх країнах світу першочерговим є здоров'я населення. Несприятливий стан екології, численні стреси, надзвичайна напруженість у повсякденному житті людини сприяють розвитку і хронізації різних захворювань, що передаються з покоління в покоління. Збільшуються масштаби таких захворювань, що загрожують генофонду будь-якої нації, як ВІЛ-інфекція, СНІД, наркоманія, токсикоманія, алкоголізм [1].

У країні негативні тенденції в стані здоров'я людей значно ускладнюються соціально-економічними і адміністративно-управлінськими кризами, які прийняли затяжний характер і багаторазово збільшують проблеми охорони здоров'я та соціального захисту населення. Катастрофічних масштабів досяг рівень серцево-судинних, онкологічних, психічних, соціальних і безлічі інших захворювань. При цьому на тлі загального збільшення попиту на медичні послуги відбувається зростання дефіциту матеріальних і фінансових ресурсів забезпечення цієї сфери. Сьогодні на-

(c) H. Фурсо, 2020 віть фінансування з бюджетів усіх рівнів та за рахунок коштів соціального страхування не може забезпечити населення загальнодоступною і якісної допомогою.

Крім того, українська система охорони здоров'я в цілому страждає від незбалансованості медичних кадрів, неефективної підготовки та використання сестринського персоналу. Безумовно, збереження основних тенденцій може спричинити поступове виродження нації.

Тим часом, сьогодні в розвинених країнах кардинально змінилося саме розуміння здоров'я і хвороби. Сформувалася потреба справлятися з різними станами організму людини, які обмежують їі фізичну й інтелектуальну активність, зумовлюють стан [8].

Основна частина. Сестринська справа - це «дія по використанню середовища, яке оточує пацієнта, з метою сприяння його одужанню». Сестринська справа ґрунтується на знаннях і техніці, створених на базі гуманітарних і природничих наук: біології, медицини, психології, соціології та інших.

Медсестра бере на себе відповідальність і діє з належними повноваженнями, безпосередньо ви- 
конуючи професійні обов'язки. Вона відповідає за ті медичні послуги, які надає. Медична сестра має право самостійно оцінювати і вирішувати, чи потрібно їй продовжити освіту з питань управління, навчання, роботи в клініці й наукових досліджень та зробити кроки, щоб задовольнити ці потреби.

Сестринська справа включає планування та надання допомоги під час хвороби і реабілітації, розглядає вплив різних аспектів життя людини на здоров'я, хворобу, інвалідність і смерть.

Що таке сестринська справа? Трактування цього поняття залежить від економічного, соціального і географічного положення країни, існуючої системи охорони здоров'я та рівня її розвитку, структури персоналу медсестер з певними функціональними обов'язками, ставлення медичного персоналу та суспільства до сестринської справи. Тому характеристики сестринської справи, дані лікарем, медичною сестрою, пацієнтом, його родичами, адміністрацією лікувального закладу і законодавчими органами, будуть істотно відрізнятися [4].

Існує кілька класичних визначень, що відображають суть і поняття сестринської справи. Легендарна Флоренс Найтінгейл у 1859 р. охарактеризувала його як «дія по використанню середовища, яке оточує пацієнта, з метою сприяння його одужанню». Завдання медсестри полягає у створенні для хворого таких умов, при яких природа надавала б свою цілющу дію. Догляд за хворими і догляд за здоровими людьми - це дві важливі сфери сестринської справи. При цьому догляд за здоровими - це «підтримка у людини такого стану, при якому хвороба не настає», а догляд за хворими це «допомога тим, хто страждає від хвороби, жити найбільш повноцінним життям, що приносить задоволення». «По суті своїй сестринська справа, як професія, відрізняється від лікарської діяльності і вимагає спеціальних, відмінних від лікарських знань», а крім цього - «організації, практичної і наукової підготовки».

Класичним вважають визначення, яке сформулювала американська медична сестра і викладач Вірджинія Хендерсон у 1961 р. і яке отримало міжнародне визнання: «Сестринська справа - це надання допомоги людині, хворій чи здоровій, в здійсненні тих дій, які мають відношення до її здоров'я, одужання або спокійної смерті, які вона зробила би сама, володіючи необхідними силами, знаннями і волею. І робити це таким чином, щоб людина знову якомога швидше здобула незалежність» [3].

Комітет експертів ВООЗ ще в 60-ті роки XX ст. визначив сестринську справу як «практику людських взає- мин», де медична сестра «повинна вміти розпізнати потреби хворих, що виникають у зв'язку з хворобою, розглядаючи хворих як індивідуальні людські істоти».

Інше визначення дали американські медичні сестри в 1984 р.: «Медична сестра - людина, яка плекає та оберігає. Вона підготовлена, щоб доглядати за хворими, пораненими та людьми похилого віку».

На нараді національних представників Міжнародної Ради сестер (1987) було запропоновано дещо інше формулювання: «Сестринська справа $є$ складовою частиною системи охорони здоров'я і включає в себе діяльність щодо зміцнення здоров'я, профілактики захворювань, надання психосоціальної допомоги і догляду особам, які мають фізичні та психічні захворювання, а також непрацездатним всіх вікових груп. Таку допомогу надають медичні сестри як у лікувальних, так і в будь-яких інших установах, а також вдома, скрізь, де в ній $є$ потреба».

На Всеукраїнській науково-практичній конференції з теорії сестринської справи (1992) було дано таке визначення цієї науки: «Сестринська справа - частина медичного догляду за пацієнтом, його здоров'ям, наука і мистецтво, спрямовані на вирішення існуючих і потенційних проблем зі здоров'ям в умовах навколишнього середовища, що змінюються».

У чому ж полягає відмінність сестринської справи, як професії, від діяльності лікаря? Всі знання і практичні дії лікаря спрямовані на виявлення та лікування хвороби у конкретної людини. Лікарська робота, будь то лікування, викладання або дослідження, розглядає різні аспекти патологічних станів конкретних хвороб. Але хвороба ставить перед хворим, його сім'єю, колективом, в якому він працює чи навчається, ще цілий ряд питань і проблем. Наприклад, лікарі врятували життя людині, постраждалому після тяжкої черепномозкової травми, але не змогли через тяжку травму і ушкодження зорових нервів зберегти йому зір. У пацієнта і його близьких виникають серйозні проблеми, які вони не в змозі вирішити без допомоги медичної та соціальної служб, суспільства.

Таким чином, сестринська справа орієнтована більшою мірою на людину або групу людей (сім'я, колектив, суспільство), ніж на хворобу; спрямована на вирішення проблем, що виникли і можуть виникнути у людини в зв'язку з погіршенням здоров'я. Отже, сестринська справа - це самостійна професія, яка має достатній потенціал, щоб стати такою ж важливою, як лікувальна справа. Функції медичної сестри значно ширші, ніж просте виконання вказівок лікаря. На неї покладено основні обов'язки із догляду за пацієнтами,

26 ISSN 2411-1597. МЕДСЕСТРИНСТВО. 2020. № 1 
профілактики захворювань, збереження здоров'я, реабілітації і полегшення страждань. Вона повинна бути прекрасним керівником (на будь-якому рівні), мати задатки лідера, менеджера, педагога і психолога.

Хто вона, медична сестра, - слухняний помічник або активний учасник? Як визначити міру її відповідальності, згоди або незгоди з діями лікаря? Поряд із розвитком медицини одночасно збільшується небезпека, якій піддається людина, потрапляючи в сферу медичних дій. При швидкому зростанні кількості населення, зниженні рівня життя серед жителів планети актуальними стають такі принципи надання медичної допомоги, як ефективність, рівність, безпека. Це ще одна з причин високих вимог до професії медичної сестри, головна місія якої полягає в наданні висококваліфікованої та спеціалізованої медичної допомоги [5].

Основні цілі сестринської справи:

- пояснювати населенню і адміністрації лікувальнопрофілактичних установ важливість і пріоритетність сестринської справи;

- розвивати і ефективно використовувати сестринський потенціал шляхом розширення професійних обов'язків і надання медичних послуг, що максимально задовольняють потреби населення;

- забезпечувати безперервний навчальний процес для підготовки висококваліфікованих медичних сестер і менеджерів сестринської справи, а також проводити післядипломну підготовку фахівців середньої і вищої сестринської ланки;

- виробляти у медичних сестер певний стиль мислення [7].

Навички спілкування - важлива частина сестринської справи. Медичній сестрі необхідно не тільки знати анатомію і фізіологію для розуміння будови i функцій людини, а й розбиратися в міжособистісних аспектах людських стосунків. У силу своїх функціональних обов'язків медичний працівник повинен

\section{СПИСОК ЛІТЕРАТУРИ}

1. Баррет К. Сестринский процесс и документация / К. Баррет, Д. Ричардсон // ВОЗ. Европейское региональное бюро, 1996. - Гл. 4.

2. Бахтіна І. С. Сестринська справа: менеджмент і лідерство / І. С. Бахтіна. - СПб. : «Синтез-Поліграф», 2002.

3. Греков І. Г. Ставлення медсестер до своєї професійної діяльності / І. Г. Греков // Медична сестра. - 2000. - № 1.

4. Іванюшкін А. Я. Історія і етика сестринської справи : навчальна допомога / А. Я. Іванюшкін. - М. : ГОУ ВУНМЦ, 2003.

5. Іванюшкін А. Я. Етика сестринської справи / А. Я. Іванюшкін. - М. : «Грант», 2003. вміти налагоджувати, заохочувати і підтримувати спілкування з пацієнтами.

Сестринська справа - це насамперед спілкування людини з людиною. У пацієнтів можуть виникати найрізноманітніші потреби в спілкуванні - в будь-який момент їм може знадобитися порада, розрада, консультація. У цій сфері діяльності багато що залежить від навичок і досвіду медпрацівника. Дуже важливо розуміти, коли пацієнт потребує інформації, підтримки або спілкування. Щоб встановити добрі взаємини від медичної сестри потрібні значні навички, включно вміння слухати, ставити питання, підбадьорювати і проявляти теплоту [4].

Усі елементи спілкування тісно пов'язані між собою; головне в цьому процесі - розуміння, вивчення особистості пацієнта, вміння налагоджувати взаєморозуміння. Для цього потрібні повага і віра в значущість, цінність, унікальність, доброта і сила іншої людини, а також її здатність і право керувати власними діями.

Медсестра не зможе грамотно надавати допомогу, якщо не буде знати і розуміти себе як особистість. Особистість - це все поняття, переконання, які складають самосвідомість індивідуальності та впливають на взаємостосунки з іншими [2].

Висновки. Сестринський процес - це наукова основа сестринської справи, за мету ставить підтримку і відновлення незалежності пацієнта, задоволення основних потреб організму.

Сучасні уявлення про розвиток сестринської справи в суспільстві полягають в тому, щоб допомогти окремим людям, сім'ям і групам розвинути свій фізичний, розумовий та соціальний потенціал і підтримувати його на відповідному рівні незалежно від мінливих умов проживання і роботи. Це вимагає від медсестри роботи зі зміцнення та збереження здоров'я, а також з профілактики захворювань.

6. Мамаєва Н. А. Значення сестринської педагогіки для підвищення якості медичної допомоги геронтологічним пацієнтам / Н. А. Мамаєва, Г. М. Злобіна // Головна медична сестра. - 2004. - № 5.

7. Мухіна С. А. Теоретичні основи сестринської справи : у 2-х ч. / С. А. Мухіна, І. І. Тарновська. - М. : Джерело, 1996.

8. Цуцунава М. Р. Медсестринське дослідження: назустріч передовій сестринській практиці / М. Р. Цуцунава // Головна медсестра. - 2001. - № 1.

Отримано 03.02.20 ISSN 2411-1597. МЕДСЕСТРИНСТВО. 2020. № 127 